\title{
Wpływ diety redukcyjnej na właściwości fizyko-chemiczne i biochemiczne śliny - przegląd piśmiennictwa
}

\author{
The impact of obesity on the physicochemical \\ and biochemical changes occurring in the saliva \\ Katedra i Klinika Stomatologii Zachowawczej i Periodontologii \\ Uniwersytet Medyczny im. Karola Marcinkowskiego w Poznaniu
}

DOI: http://dx.doi.org/10.20883/df.2016.13

\begin{abstract}
Streszczenie
W ciągu ostatnich lat Światowa Organizacja Zdrowia określiła otyłość mianem epidemii naszych czasów. Coraz więcej doniesień naukowych zwraca uwagę na korelację pomiędzy otyłością a zmianami fizyko-chemicznymi i biochemicznymi zachodzącymi w ślinie. Pomimo alarmujących doniesień występowanie nadwagi i otyłości wzrasta niezmiennie w ciągu ostatnich 30 lat. Podstawą leczenia otyłości jest uzyskanie ujemnego bilansu energetycznego, co jest możliwe dzięki zwiększeniu aktywności fizycznej i wprowadzeniu diety o obniżonej wartości energetycznej w stosunku do zapotrzebowania. Dietą najczęściej stosowaną w leczeniu otyłości jest dieta bardzo niskoenergetyczna (VLCD) dostarczająca 200-800 kcal na dobę. Nie do końca jednak poznany jest wpływ restrykcji dietetycznych na funkcjonowanie gruczołów ślinowych. W pracy przedstawiono najnowsze doniesienia na temat wpływu diety redukcyjnej na właściwości fizyczne, chemiczne i mikrobiologiczne śliny.
\end{abstract}

Słowa kluczowe: ślina, otyłość, zdrowie jamy ustnej, dieta bardzo niskokaloryczna (VLCD).

\begin{abstract}
Recently, the World Health Organization classified obesity as an epidemic disease of the modern era. More and more scientific reports draw attention to a correlation between obesity and the physio-chemical and biochemical changes occurring in the saliva. Studies continue to show that adults and adolescents utilise different types of diets to lose or maintain weight. Nevertheless, the prevalence of overweight and obesity has been increasing continuously over the last 30 years. The basis for the treatment of obesity is to achieve a negative energy balance, which is possible through the implementation of an energy-reduced diet in relation to a patient's needs and increased physical activity. One of the methods used in the treatment of obesity is the use of a very low calorie diet (VLCD), which provides 200-800 kcal per day. A VLCD diet is considered to be a diet that reduces body weight, which in turn is associated with a reduction in hypertension, dyslipidemia and diabetes.
\end{abstract}

Keywords: saliva, obesity, oral health, very low calorie diet (VLCD).

\section{Otyłość}

W XXI wieku otyłość stanowi jeden z najpoważniejszych problemów zdrowia publicznego $w$ wielu krajach całego świata. Według danych Światowej Organizacji Zdrowia z 2015 r. 2,3 mld ludzi na Ziemi ma nadwage, a $700 \mathrm{mln}$ cierpi z powodu otyłości. Jeszcze w roku 2006 było to odpowiednio 1,6 mld oraz $400 \mathrm{mln}$ [1]. Szacuje się, że obecnie $64 \%$ mężczyzn w Polsce cierpi z powodu nadmiernej masy ciała, w przypadku kobiet odsetek ten sięga już 49\%. Co gorsza, chorują nie tylko dorośli, ale również dzieci i młodzież. Jeszcze w latach 70. ubiegłego wieku nadmierną masę ciała notowano w Polsce u mniej niż $10 \%$ uczniów, podczas gdy obecnie już co piąte dziecko $\mathrm{w}$ wieku szkolnym boryka się z problemem nadwagi lub otyłości [2].

Już od kilku lat rządy wielu krajów prowadzą szeroko zakrojone akcje profilaktyczne mające na celu promocję podstawowych działań, które przy- czyniłyby się do zapobiegania nadwadze i otyłości i tym samym pozwoliłyby zmniejszyć zachorowalność i umieralność z powodu chorób spowodowanych otyłością. Należą do nich choroby układu krążenia, nowotwory, cukrzyca typu II i nadciśnienie tętnicze. Lepsza profilaktyka to także możliwość zmniejszenia wydatków na ochronę zdrowia związanych z leczeniem ww. chorób, a także skutków ekonomicznych niepełnosprawności i przedwczesnej umieralności.

Podstawą leczenia otyłości jest uzyskanie ujemnego bilansu energetycznego, co jest możliwe dzięki wprowadzeniu diety o obniżonej energetyczności w stosunku do zapotrzebowania pacjenta. Modyfikacja zachowań żywieniowych, tuż obok wzmożenia aktywności fizycznej, to jedna ze skuteczniejszych metod walki z otyłością. Wyniki wielu badań klinicznych wskazują, iż redukcja masy ciała przynosi istotne korzyści zdrowotne [3, 4]. 


\section{Dieta w leczeniu otyłości}

Powstrzymywanie się od spożywania pokarmów jako metoda leczenia znane jest od stuleci. Ojciec medycyny, Hipokrates, nic nie podawał choremu do ust, dopóki nie pojawiały się pierwsze symptomy poprawy zdrowia. Rzymski lekarz Galen głosił, że okresowe powstrzymywanie się od pokarmów równomiernie oczyszcza całe ciało. Arabski uczony Awicenna (X/XI w.) leczenie głodem uważał za jedną z najważniejszych metod terapeutycznych. Post lub głodówka obecne są także we wszystkich wielkich religiach świata [4].

W celu redukcji masy ciała stosowane są różne rodzaje diet. Do najczęściej badanych i opisywanych w literaturze należą: dieta niskoenergetyczna, dieta bardzo niskoenergetyczna, dieta niskowęglowodanowa (VLCD, very low calorie diet) i wysokobiałkowa [5]. Główne różnice w założeniach tych diet polegają na zmiennej zawartości makroskładników, tzn. tłuszczów, węglowodanów i białek. VLCD to diety, w których kaloryczność wynosi $200-800 \mathrm{kcal}$ na dobę. Są to diety w postaci saszetek z proszkiem do przygotowania posiłków, które opracowano na potrzeby leczenia pacjentów hospitalizowanych. Są to diety wysokobiałkowe i bardzo niskowęglowodanowe, wzbogacone w witaminy i mikroelementy oraz niezbędne kwasy tłuszczowe. Te wysokobiałkowe i wysokotłuszczowe również mają wpływ ketogenny; hamując odczuwanie głodu i zawierając wyższe niż zalecane ilości cholesterolu, mogą sprzyjać rozwojowi miażdżycy. Diety wysokobiałkowe zawierają również większą od zalecanej zawartość fosforanów, co powoduje zaburzenia wchłaniania wapnia. Przy dłuższym ich stosowaniu mogą więc spowodować rozwój osteoporozy [5].

Skład oraz kaloryczność wymienionych diet indukują wytwarzanie się w organizmie stanu ketozy, która hamuje odczuwanie głodu. Znaczna początkowa redukcja masy ciała jest spowodowana zużyciem zapasów glikogenu, co wiąże się z utratą 2-3 I wody, utratą związków ketonowych z moczem oraz zwiększoną diurezą. Następnie tempo redukcji masy ciała jest wolniejsze i wynika ze zużywania zapasów energetycznych zmagazynowanych w tkance tłuszczowej [6]. W przypadku pacjentów otyłych już niewielka utrata wagi indukuje pozytywne zmiany w metabolizmie, co dowodzi, jak ważne jest ograniczenie kalorii [7].

\section{Wpływ diety na wydzielanie i skład śliny}

Już od połowy XX wieku badacze zajmowali się zagadnieniem wpływu diety na potencjalne zmiany właściwości fizyko-chemicznych śliny. Nie od dziś wiadomo, iż pokarmy wymagające intensywnego żucia w większym stopniu zwiększają przepływ śliny, natomiast badania naukowe dotyczące wpływu diety niskokalorycznej na działalność wydzielniczą ślinianek są bardzo interesujące. Erics- son wykazał, że dieta bogata w białko lub produkty roślinne powoduje wzrost pH i pojemności buforowej, podczas gdy dieta bogata w węglowodany zmniejsza zarówno pH, jak i pojemność buforową śliny [8]. Wyniki badań odnośnie wydzielania śliny nie są jednak jednoznaczne: Linkosalo i wsp. zauważyli, że szybkość wydzielania śliny stymulowanej jest niższa u pacjentów będących na diecie laktowegetariańskiej niż u osób odżywiających się normalnie. Także pH pobieranej śliny różniło się między grupami i u osób na diecie było istotnie niższe [9]. W kolejnych badaniach prowadzonych u pacjentów-wegetarian Johansson i Ravald potwierdzili tezę o szybszym wydzielaniu śliny u pacjentów na diecie bezmięsnej [10]. Co ciekawe, powrót do diety mieszanej wskazywał na tendencję do zwiększania szybkości wydzielania śliny [11]. Wielu autorów sugeruje także, iż uboga dieta i nieodpowiednie odżywianie mogą być czynnikami ryzyka przewlekłego zapalenia przyzębia oraz w niekorzystny sposób zmieniać jego przebieg $[12,13]$.

Wspomniana dieta lakto- oraz laktoowowegetariańska, eliminująca wszystkie produkty mleczne może być przyczyną niedoborów wapnia, który ma pośredni wpływ na stan tkanek przyzębia poprzez swój udział w regulacji gęstości kości szkieletu i wyrostka zębodołowego. Również stan tkanek twardych zębów może pogorszyć się wskutek zbyt niskiego stężenia jonów wapnia w ślinie.

Od dawna znana jest również zależność pomiędzy niedoborem witaminy $\mathrm{C}$ a zapaleniem przyzębia. Wielu badaczy wykazało związek pomiędzy utratą przyczepu łącznotkankowego oraz zwiększonym ryzykiem rozwoju zapalenia przyzębia a niskim poziomem witaminy $\mathrm{C}$ w osoczu krwi [14-16]. Szczególnie niebezpieczne dla zdrowia jamy ustnej wydają się być niedobory witaminy $A$, które mogą prowadzić do atrofii śluzówki, kserostomii oraz leukoplakii $[17,18]$.

Również niedobory witamin z grupy B przyczyniają się do spadku odporności na infekcje oraz zaburzeń w procesach gojenia, co może również wpływać na podatność tkanek przyzębia na patogeny, przebieg choroby i jej leczenie. Brak lub niedostateczny poziom tej witaminy prowadzi do załamania bariery nabłonkowej, co szczególnie widoczne jest u osób starszych [19].

Niezmiernie ważne wydaje się dostarczanie wraz z pożywieniem antyoksydantów, które zapewnia dieta bogata w owoce, warzywa i pieczywo pełnoziarniste. Zależność między przyjmowaniem produktów spożywczych zawierających antyoksydanty a zapaleniem przyzębia może polegać na ochronie tkanek przed zniszczeniem wywołanym reaktywnymi formami tlenu [19]. Nie tylko świeże warzywa i owoce potrzebne są do prawidłowego funkcjonowania komórek i tkanek. Wykazano, iż nienasycone kwasy tłuszczowe, których bogatym źródłem są oleje roślinne, ryby morskie oraz żółt- 
ko jaja, mogą blokować uszkodzenie tkanek indukowane przez neutrofile [19-21].

Z piśmiennictwa wynika również, że radykalna zmiana diety może mieć wpływ na stężenie immunoglobuliny A zarówno w ślinie, jak i surowicy krwi. Ślinowa IgA (slgA) jest uważana za najistotniejszy czynnik odporności swoistej w środowisku jamy ustnej. Cząstka ta wiąże antygeny bakterii, przez co osłabia ich adhezję do błony śluzowej jamy ustnej i tkanek twardych zębów. Pełni więc istotną rolę w zachowaniu homeostazy środowiska jamy ustnej. Obniżenie poziomu slgA zaobserwowano między innymi u osób niedożywionych [22, 23].

Wśród badaczy trwa także dyskusja na temat wpływu diety wegetariańskiej oraz wegańskiej na poziom obecnej w ślinie IgA [24]. Herman i Piesiak-Pańczyszyn wykazali niższe stężenie $\lg A$ w ślinie wegetarian [25], czego nie potwierdzili Johansson i wsp. Bardzo interesujące wydają się być badania Younga i wsp., wskazujące, iż umiarkowane zmniejszenie spożycia żywności wywoływało przerost ślinianki przyusznej u szczurów [26]. Zjawisko to najprawdopodobniej wiąże się ze zwiększonym magazynowaniem białek wydzielniczych. Ci sami badacze wykazali także, iż zwiększenie ilości celulozy w diecie szczurów również wywołuje powiększenie gruczołów ślinowych [27].

Wyniki badań wskazują, że 8-dniowa ścisła dieta może doprowadzić do powstania zmian jakościowych w ślinie: w ślinie kobiet pozostających na diecie stwierdzono m.in. znaczne obniżenie się stężenia fosforanów oraz kwasu sialowego [28]. Alam i współpracownicy również wykazali powiązanie diety ze zmianami właściwości śliny. Prowadząc swoje badania u małp zaobserwowali, iż zwiększenie poziomu kwasu linolowego w diecie znacząco wpłynęło na podwyższenie poziomu tego kwasu w ślinie [29]. Z pewnością bardzo pozytywną korelację pomiędzy dietą a zmianami biochemicznymi w ślinie wykazali Vasaghi-Gharamaleki i wsp. badający irańskich muzułmanów w trakcie ramadanu: po miesięcznym poście poziom kortyzolu w ich ślinie był istotnie niższy [30].

Omawiając rolę pokarmów nie sposób pominąć fizycznego charakteru diety. Typ i ilość spożywanych produktów spożywczych może również wpływać na formowanie złogów płytki nazębnej. Przyjmowanie pokarmów o konsystencji papkowatej czy kleistej niesie za sobą pogorszenie warunków higienicznych w jamie ustnej, a tym samym sprzyja rozwojowi stanów zapalnych. Natomiast twarda konsystencja diety, dzięki procesowi żucia, prowadzi do zwiększenia szybkości wydzielania śliny, co wpływa na oczyszczanie jamy ustnej.

\section{Podsumowanie}

Restrykcje dietetyczne stosowane jako terapia bądź jej uzupełnienie znane są już od tysiącleci. W XXI wieku, gdy epidemia otyłości zatacza coraz szersze kręgi, leczenie za pomocą diety wydaje się być najbardziej skuteczne. Niskoenergetyczne diety stosowane w leczeniu otyłości powodują znaczny ubytek masy ciała, jednak takie postępowanie powinno się odbywać pod kontrolą i na zlecenie lekarza. VLCD nie należy traktować jako jedynego środka do uzyskania redukcji masy ciała, a tylko jeden ze sposobów, który może ją wspomóc.

Diety wysokobiałkowe i wysokotłuszczowe nie mogą być alternatywą dla gotowych diet VLCD, ponieważ zawierają wyższe niż zalecane ilości cholesterolu, co sprzyja rozwojowi miażdżycy. W celu zmniejszenia ubytku beztłuszczowej masy ciała konieczne jest równoczesne zwiększenie aktywności fizycznej oraz odpowiednia edukacja dietetyczna [31].

Obok korzyści wynikających z redukcji tkanki tłuszczowej, restrykcja dietetyczna wywiera także znaczny wpływ na funkcjonowanie gruczołów ślinowych, skład i ilość wydzielanej śliny.

\section{Oświadczenia}

\section{Oświadczenie dotyczące konfliktu interesów}

Autorzy deklarują brak konfliktu interesów w autorstwie oraz publikacji pracy.

\section{Źródła finansowania}

Autorzy deklarują brak źródeł finansowania.

\section{Piśmiennictwo}

[1] World Health Organization. Interim Report of the Commission on Ending Childhood Obesity. Genewa 2015.

[2] Instytut Żywności i Żywienia Musimy zatrzymać epidemię otyłości. Warszawa 2015.

[3] Poirier P, Giles TD, Bray GA i wsp. Obesity and cardiovascular disease: pathophysiology, evaluation, and effect of weight loss. Circulation. 2006;113:989-918.

[4] Buczko W. Pościć albo nie pościć? Medyk Białostock. 2009;73:26-28.

[5] Kłosiewicz-Latoszek L. Otyłość jako problem społeczny, zdrowotny i leczniczy. Probl Hig Epidemiol. 2010;91(3):339-343.

[6] Kaplan GD, Stifler L.T. Very low-calorie diets for obesity. JAMA. 1994;271:24-25.

[7] Henry RR, Gumbiner B. Benefits and Limitations of Very-Low-Calorie Diet Therapy in Obese NIDDM. Diabetes Care. 1991;14(9):802-823.

[8] Ericsson Y. Clinical investigations of the salivary buffering action. Acta Odont Scand. 1959;17:131-165.

[9] Linkosalo E, Ohtonen S, Markkanen H. Caries, periodontal status and some salivary factors in lactovegetarians. Scand J Dent. 1985;93(4):385-396.

[10] Johansson G, Ravald N. Comparison of some salivary variables between vegetarians and omnivores. Eur $\mathrm{J}$ Oral Sci. 1995;103:95-98.

[11] Johansson G, Birkhed D. Effect of a long-term change from a mixed to a lactovegetarian diet on human saliva. Archs. Oral Biol. 1994;39(4):283-288.

[12] Al-Zahrani MS. Increased Intake of Dairy Products Is Related to Lower Periodontitis Prevalence. J Periodontol. 2006;77(2):289-294.

[13] Al-Zahrani MS. Bissada NF, Borawski EA. Diet and periodontitis. J Int Acad Periodontol. 2005;7(1):21-26.

[14] Borakowska-Siennicka M. Wpływ diety na stan tkanek przyzębia - na podstawie piśmiennictwa. Nowa Stomatologia. 2012;3:130-133.

[15] Carr A, Frei B. Toward a new recommended dietary allowance for vitamin $C$ based on antioxidant and health effects in humans. Am J Clin Nutr. 1999;69:1086-1107. 
[16] Maćkowiak K, Torliński L. Współczesne poglądy na rolę witaminy C w fizjologii i patologii człowieka. Nowiny Lekarskie. 2007;76(4):349-356.

[17] Frydrych A, Davies G, McDermot B. Eating disorders and oral health: A review of the literature. Australian Dent J. 2005;50:1.

[18] Kayser-Jones RJ. Malnutrition, Dehydration, and Starvation in the Midst of Plenty: The Political Impact of Qualitative Inquiry. Oral Health. 2012;12:1391-1405.

[19] Kantorowicz M, Chomyszyn-Gajewska M, Olszewska-Czyż I, Łazarz-Bartyzel K. Odżywianie a choroby przyzębia. Przegląd Lekarski. 2013;7(1): 28-30.

[20] Food consumption, body mass index and risk for oral health in adolescents. Atencion Primaria. 2014;46(5):154159.

[21] Barroso E Martin V, Martinez-Cuesta C, Pelaez C, Roquena T. Stability of saliva mikrobiota during moderate consumption of red wine. Arch Oral Biol. 2015;60(12):17631768.

[22] Marcotte H, Lavoie M.C. Oral Microbial Ecology and the Role of Salivary Immunoglobulin A. Microbiol Molecul Biol Review. 1998;62,(1):71-109.

[23] Malicka B, Kaczmarek U, Skośkiewicz-Malinowska K. Selected antibacterial factors in the saliva of diabetic patients. Arch Oral Biol. 2015;60(3):425-431.

[24] Jankowska A, Waszkiel D, Kobus A, Zwierz K. Ślina jako główny składnik ekosystemu jamy ustnej. Wiad Lek. 2007;60:253-257.

[25] Herman K, Piesiak-Pańczyszyn D. Wpływ diety wegetariańskiej na poziom wydzielniczej immunoglobuliny A w ślinie. Dent. Med. Probl. 2008;45(4):407-412.

[26] Marosti A. de Almeida F, Franzoi de Moraes S, Molinari $S$, Marcal Natali M. Effects of the cafeteria diet on the salivary glands of trained and sedentary Wistar rats. Acta Scientarum Biol Sciences. 2012;34(1):113-118.
[27] Johnson DA. Changes in rat parotid salivary proteins associated with liquid diet-induced gland atrophy and isoproterenol-induced gland enlargement. Arch Oral Biol. 1984;29(3):215-221.

[28] Johansson I, Ericson T, Steen L. Studies of the effect of diet on saliva secretion and caries development: the effect of fasting on saliva composition of female subjects. J Nutr. 1984;114(11):2010-2020.

[29] Alam AQ Alam BS. Effect of dietary lipids on saliva composition. J Nutr. 1982;112(5):990-996.

[30] Vasaghi-Gharamaleki A, Mirzaii-Dizgah A. Unstimulated whole saliva cortisol levels during Ramadan in Iranian Muslims. J Contemp Dent Pract. 2014;15(3):341-344.

[31] Olszanecka-Glinianowicz M. Rola diety bardzo niskokalorycznej (VLCD) w leczeniu otyłości. Endokrynologia, otyłość i Zaburzenia Przemiany Materii. 2012;4(8):109-113.

[32] Herman K. Influence of Vegetarian Diet on Calcium, Magnesium and Carbonate Level in Saliva. Dent Med Probl. 2007;44(2):172-176.

Zaakceptowano do edycji: 2016-05-02 Zaakceptowano do publikacji: 2016-05-12

\author{
Adres do korespondencji: \\ Collegium Stomatologicum \\ Uniwersytet Medyczny im. Karola Marcinkowskiego \\ w Poznaniu \\ ul. Bukowska 70, 60-812 Poznan \\ tel.: +48 618547050 \\ e-mail: marzenadabrowska123@gmail.com
}

